\title{
A Brief Review of Meira Paibi: A Women's Movement in Manipur
}

\author{
Aruna Chanu Oinam ${ }^{1}$ and Purnima Thoidingjam ${ }^{2}$ \\ ${ }^{1}$ Research Scholar, ${ }^{2}$ Professor \\ Library and Information Science, Manipur University, Imphal, Manipur, India \\ E-mail: arunaoinam44@gmail.com
}

\begin{abstract}
The Meira Paibi (Also popularly known as Women torch bearers) used torch as a weapon to fight against social injustice of various forms in Manipur. Every woman in Manipur becomes Meira Paibi during difficult situation which directly affects the communities. In pre and post-independence period of India, various women organizations played a pivotal role fighting against social injustice in the society. One such group is Meira Paibai formed from the one of largest population in Manipur. In 1904 and 1939 elderly women in the age group of $50-70$ years came together in forming Meira Paibai group and they were also called as "IMAS" meaning mothers in Manipuri. But in post-independence all age group women were involved in Meira Paibai organization. The origin of civil society in India can be traced back to Vedic periods and consisted mainly of men in those movements. On the contrary in Manipur it was led by the women against various issues such as injustice done by British government, Manipur maharaja economic policies in pre-independence and against social and administrative problems in the post-independence era. This movement should be role model to every woman to know their responsibilities and their contribution in developmental process. As rightly told by UNICEF; The Manipur story indicates that active participation by women in public affairs can and does contribute to better conditions for children and society at large.
\end{abstract}

Keywords: Meira Paibai, Civil movements, Manipur, Injustice.

\section{INTRODUCTION}

The peace and harmony in any society is a key factor for the growth and development in any country. The people irrespective of gender and age should work together in solving the issues of the society. Since long women in this country were suppressed by male especially in civil society movements. The male dominated organizations were in view that women can't be part of civil society movement.

According to Edwards, M (2004) the civil society is a very important word and is essentially "the big idea on everyone's lips". According to Merkel, W., and H. Lauth.(1998) there is no definite definition of civil society and suggested that it's an idea in general terms with voluntary, uncoerced collective action around shared interests, purposes and values. It should be emphasized that John Locke was the first one in modern times to stress that civil society should be understood as a body in its own right, separate from the state. He also suggested that people form a community, in which their social life develops and in which the state has no say. This sphere is pre- or un- political. The first task of this civil society is to protect the individual - specifically his/her rights and property - against the state and its arbitrary interventions (Schade, J, 2002). This further can be expanded to protecting own, family, society and at large community interests.

According to Mishra, Kailash K. (2002) the roots of civil society in India was traced back to ancient times, where the people of thousands of castes, all major religions and more than 427 odd Tribal communities have been living and maintaining an exemplary communal harmony.

It was evident that civil society has been existed since Vedic times. The formation and mobilization has been evident since colonial period in various countries. The western countries simultaneously with civil society, a process covering centuries and included a gradual shift towards a more powerful and efficient state, but also towards a stronger and more independent civil society, the development of civil society in the rest of the world has not followed the same pattern (Kaviraj and Khilnani. (ed), 2001).

In every country, there will be problems with governments be at state or central level. The political inclinations/interventions had higher impact on administrative function in any political atmosphere. This eventually led to partial or complete failure of administrative work in various places of the country. This directly affects the services provided by the government to the people. In this situations somebody need to stand up against this injustice. This led to birth of civil society to address and solve the issues be it a social or economic which affects the communities at large.

The civil society formed from like-minded people consisted of people from different sections with various level of education background. These are individuals with common ideology and goal came together to serve the country across various parts. The importance and responsibilities have been increasingly recognized by the society in recent times. According to Vijender Singh. (2012), the civil society organizations and their networks contributed at various levels such as national, political, improvement of governance and help to build cohesive relationship in society. According to Vijender Singh (2012), the main objectives for civil society organizations were; 
1. Having a responsive political and bureaucratic system.

2. Having appropriate policies for the poor

3. Playing a watch dog role in proper allocations for the schemes in their society.

4. Having participatory, decentralized and efficient implementation of the programs.

5. Having transparent and accountable system.

6. Having a quick and fair justice where poor can get justice at low cost and quickly.

\section{BRIEF OUTLINE ABOUT MANIPUR STATE}

Manipur is a state located in India's North East. Manipur preserves a religion rich in mythology and colorful rituals. Manipur meaning "land of gems" is a sanskritized name given to the land when Meiteis I.e. the people of plains adopted Vaishnavism as a state religion in the $18^{\text {th }}$ century A.D. (Rena Laisram, 2009)

Manipur is one of the 28 states of India, situated on the country's north east. The state covers an area of 22,347 square kilometers with 2,721,756 inhabitants. The state is bordered by Nagaland to the north, Mizoram to the south and Assam to the west; it also borders Burma to the east (Manipur at glance, 2013).

The capital of Manipur is Imphal. The primary official language of Manipur is Meiteilon. English is also slowly gaining ground as a common language of communication. Hindi is also in use by the migrants from northern India. The state has the good quality of life in the country with excellent physical infrastructure and it has 79.85\% literacy level.

\section{MANIPUR INDEPENDENCE}

Manipur got the independence from the British rule in 1947. A responsible form of government was established in Manipur in 1947 under the Manipur State Constitution Act, 1947. The constitution was enacted by the caretaker who was nominated by the Maharaja of Manipur, Shri Bodhachandra Singh with 7 members from $14^{\text {th }}$ August 1947 to $7^{\text {th }}$ August 1948.

For the first time, elections in Manipur were held on $11^{\text {th }}$ June 1948 Known as "Manipur State Assembly Elections" Under the Manipur Constitution Act. These were the first democratic elections held in Manipur (Singh, N. Sanajaoba, 1988).

On $15^{\text {th }}$ October 1949 , the state was merged in the Indian Territory as a part C State and administered by the President of India through a Chief Commissioner. It ceased to be a part C State on $1^{\text {st }}$ November, 1956 and became a Union Territory under the Union Territorial Council Act, 1956. The territorial Council consisting of 30 elected members and 2 nominated members was constituted on $16^{\text {th }}$ August 1957. However, the Territorial Council was replaced by a
Territorial Legislative Assembly of 30 members and 2 nominated members from $23^{\text {rd }}$ July 1963.The state was granted statehood in 1971 and the assembly election for 60 seats, which was earlier 30 seats, was held in 1972 (Singh, N. Sanajaoba, 1988).

\section{CIVIL SOCIETY MOVEMENT IN MANIPUR}

Civil society initiatives by women play a key role in peace and security development through their participation in conflict resolution and peace building processes. In the historical context the Meitei movement in Manipur as a community based organization has a distinct footprint in India. It's unfortunate that population of India and world doesn't have much knowledge about this exclusively women's led movement in Pre and post-independence India. This review article focuses on their movement and struggle in uplifting the community. The origin of Meitei movement which is also known as Meira Paibi movement can be traced back to pre-independence time in Manipur. It was perceived that there is always an inequality among men and women in the society which was true in many parts of the country, but this was not evident in Meitei society. The society per se has in view that both men and women are interdependent, women has equal rights in developmental process.

The women involvement in fight against political misadventures and agitations for injustice are seen very minimal in India. There were lot of factors which withheld the participation of women be it from within family members, society and community leaders, which are dominated by males.

The education and developmental process were inaccessible to women which further complicated the women participation in most parts of the country. On contrary in Manipur, community elders recognized the importance of women in development process of nation and allowed women to be engaged in social work with their innovative ideas, keeping all traditional and social values intact. This equality should be there for every woman in society and in all countries. The Manipur women movement should encourage all women in this country to know their strength and be at par with men in all fields.In Manipur historically women participated in every social sphere and worked relentlessly.

The education is one of the vital fulcrums for women to their strengths and update them self with recent knowledge. In many parts of India, the women education is not up to the mark when compared to Manipur which has women literacy $73.17 \%$ to overall India women literacy $65.46 \%$

Education provides various advantages,

1. Allows key participation in work,

2. Provides problem solving skills,

3. Provides leadership and decision making skills, 
4. Development of literacy skills such as information gathering, analyzing, processing and applying,

5. Betterment of health care,

6. Increased earning and social stability,

7. Economically empowered, not to be dependent on men.

\section{MEIRA PAIBI}

In the year 1904 when British were ruling the country, likeminded women in Manipur came together as group called Meira Paibi (Women Torch Bearers) for up lift ment of society. During those times lot of issues were happening such as injustice to Manipur people by British government.

In pre independence history TWO major movements occurred famously known as Nupi lals, one in 1904 and again second in1939 (Merina Islam, 2014). During 1904 the British government imposed restrictions on Manipur through the king such as forced labor and free trade of grains like rice to outside markets. This severely impacted the economic status of people and many suffered starvation. The women are especially finding it difficult to maintain the family and feed the children.

The women of one colony came together to protest against this injustice. Soon the movement spread across various areas leading to first Nupilan (Meira Paibai) movement. The purpose which made them to come together was fighting against repressive and discriminatory rule made by British government against people of Manipur.

The second Nupilan started in 1939 as an agitation against the economic policies of the Maharaja and the Marwari monopolists, but later on changed its character to become a movement for constitutional and administrative reforms in Manipur. Manipuri women then organized themselves and took upon the responsibility to control the rising disorder in the society. Beginning as a protest against price rise, the demand extended over to administrative reforms against the oppressive economic and administrative policies ruled by the Manipur Maharaja and the Political person-Mr Gimson of the British Government (Mukherji and Shruti , 2010).

This clearly explains that meira paibai worked as civil society when there existed a problem and later they will do their routine household work. So it's not an organization with all facilities such as buildings, Proper committee members, roles and responsibilities etc.

\section{POST-INDEPENDENCE MEIRA PAIBI MOVEMENT}

In the year 1949, Manipur was merged with Indian state. There was lot of resistance within Manipur for this move by the king of Manipur and led to formation of various groups protesting. Some groups took arms to fight against the state, in this conflict situation various youths were misguided to pick up arms against own country to become terrorists.
Many youths were addicted to various drugs and alcohol which was deleterious to society.

Manipur being the border state to Myanmar which has long history of psychotropic substance abuse with opium, cannabis, alcohol and medical drugs such as Buprenorphine, Cocktail with antihistamine injections, sedatives such as Benzodiazepines. These drugs where crossed over from the border and been circulated to youths of Manipur. The youths of Manipur trapped in insurgent affected zone together with poor management of law and order by the government aggravated the situation.

It is clearly known that inject able drugs use and its sharing is being associated with increased incidence of HIV infection (WHO Management of substance abuse, 2011).

This was one of the main problem in younger generation during those times in Manipur as many youths were addicted to drugs and alcohol.

The women were concerned as their children were ruining their life leading to various problems such as physical, psychological, social, health and occupational problems (Pratima Murthy S. Bala Shanthi Nikketha, 2007) The studies have shown that substance abuse is a complex problem having medical and social ramifications which impacts all social strata. It affects not only the user and their families but all sections of the society (Teaotia R, 2005)

It was a difficult situation as many youths addicted to these experiencing array of problems such as health related problems, education related issues, involvement in crime etc. This not only affected them but lead to poor relations in family further having serious consequences for the community and entire society.

During these times somebody needed to step in to stop this, and women from many localities in 1970s rose to the occasion and led battle against alcoholism and drug abuse. This was famously known as "Night patrollers movement". The women groups patrolled the streets after dark and any men found to be drinking were punished. They also raided liquor shops and closed them.

It was in 1975 that women in large numbers stated antiliquor movement in urban as well as in rural areas when the peaceful social order in the localities was disturbed by the persons involved in selling and drinking of liquor.

Women in the concerned localities gathered their strength and asserted their capabilities in checking and controlling the persons who were involved in the selling and drinking of liquor as well as those persons involved in the transaction of liquor business. The women in groups at this stage were known as Nisha Bandish and their organizations as Nisha bandh organizations. The initial movement against alcoholism progressed to various other issues such as drug abuse (Koni Potsangbam, 2016). 


\section{CONCLUSION}

The meaningful participation of women in the civil society brings valuable changes in the society. The women with her leadership skills are in a position to prioritize the issues at hand be it social, family, community, state or country level. Women participation has always been positive in community progress as shown in the case of Meira Paibi groups. Every woman in India must learn from such groups and get courage to fight against gender inequity, personal, family, social and community problems. The women must think themselves at par with men and come out of shadow of inequality existing in the society.

There is no one to change the status of women until the change starts from them. The women are deeply committed to solve the problems such as peace building, pre and post conflict situations, and menace in the community such as alcoholism, drug abuse etc as rightly shown by meira Paibi groups. Despite we are in $21^{\text {st }}$ century considerable challenges still remain to women participation as community leaders, mainly resistance coming from male counterparts.

But with the community leaders and elders of both gender support, women can overcome these barriers as in case of Meira Paibi. In each household, it's must that women and men take equal responsibility at all levels. These conditions and such environment should be seen around the country from the inspiration of Meira Paibi movement. Apart from forming like-minded groups these organizations must focus on more effective way of strengthening and further building of organization by conducting training sessions on communication skills, providing leadership skills, uniting all women with aim of betterment of democracy in the country, training how to get the information, exchanging the information effectively, and engaging the youths in building the nation.

\section{REFERENCES}

[1] Edwards, M. (2004). Civil Society. Cambridge: Polity. https://www.academia.edu/19440671/Civil_Society_Development_an d_its_Impact_on_the_Democratization_Process_in_Kosovo.

[2] https://www.researchgate.net/publication/320736477_ManipurAt_a_Glance. 2013.

[3] Kaviraj, \& Khilnani, (ed) (2001). Civil Society-History and Possibilities. Verso Pub.

[4] Koni Potsangbam. (2016). Meira paibis: the rise of women civil society Organizations' movement in the state of Manipur. Indian Streams Research Journal, 6(1), 1-6.

[5] Merina Islam. (2014). Evolution of meira paibi and their changing Role in meitei society. International journal of multidisciplinary educational research, 3(9), 34-42.

[6] Merkel, W., \& H. Lauth. (1998). Systemwechsel und Zivilgesellschaft. Welche Zivilgesellschaft braucht die Demokratie? Aus Politik und Zeitgeschichte, 6 (7), 3-12.

[7] Mishra., \& Kailash, K. (2002, October 7-11). Chaupal As Multidimensional Public Space for Civil Society in India. International Seminar on Folklore, Public Space and Civil Society, Indira Gandhi National Centre for the Arts, New Delhi and National Folklore Support Centre, Delhi.
[8] Mukherji., \& Shruti. (2010). Meira Paibis: Women Torch-Bearers On The March In Manipur, Mainstream, XIX (1) .https://www.mainstreamweekly.net/article2533.html.

[9] Pratima Murthy, S., \& Bala Shanthi Nikketha. (Editors). (2007). Introduction in Psychosocial Interventions for Persons with Substance Abuse: Theory and Practice, National Institute of Mental Health and Neuro Sciences (NIMHANS), Bangalore, India,

[10] Rena Laisram. (2009). Early Meitei history. Religion, society and the Manipur puyas.

[11] Schade, J. (2002). Zivilgesellschaft. Eine vielschichtige Debatte. Institut für Entwicklung und Frieden der Universität Duisburg Report Nr. 59. Duisburg: INEF.

[12] Singh N. Sanajaoba. (1988). Manipur Past and Present. New Delhi: Mittal Publication.

[13] Teaotia, R. (2005). Joint Secretary Ministry of Health and Family Welfare Government of India. Foreword massage in Drug use disorder Manual for physicians. Rakesh Lal (edit.) the National Drug Dependence Treatment Centre, AIIMS, India.

[14] Vijender Singh. (2012). An Analysis of Concept and Role of Civil Society in Contemporary India. Global Journal of Human Social Science, 12 (7), 69-77.

[15] WHO Management of substance abuse: Facts and figure s. ( 2011, 17 November). Retrieved from: http://www.who.int/ substance_abuse/facts/en. 